\title{
Science Education, Overconsumption, and Survival on a Finite Planet
}

\section{Paul Connet}

\section{Introduction}

THE YEAR W AS 2110. For three days now he had been traveling across this city, on the only transport left to him, his very weary legs. He had seen no other human being, just broken buildings. His throat ached for water. Just as he was wondering how long he could continue, he was almost blinded by the sun's rays reflecting from the mirror-like surface of a very tall structure. As he got closer he found that on the base of this strange obelisk was engraved this legend:

"They became more and more sophisticated at answering the wrong questions"

Returning to 1996, I believe that our educational systems have to address the right kind of questions if civilization, as we know it, is going to survive beyond the twenty-first century.

Elsewhere in this publication David Pimentel eloquently discusses one of these overwhelming questions, namely overpopulation. In this essay I am going to discuss another: overconsumption. We could spend a lot of time arguing about which is worse, overpopulation or overconsumption, but that would be pointless because the two problems are multiplied. We have more and more people, attempting to consume more and more.

In my view, technological progress has raced ahead of social progress. At the press of a few buttons we can talk with people all over the world, before we have mastered the art of communicating with the person who lives next door. We are racing faster and faster from parking lot to parking lot. We struggle and strive in order to sink into a couch and watch other people live on the other side of a plastic screen. We buy more and more objects to fill the void left by not building our lives around relationships. The nuclear family has become the ideal 
purchasing unit. The modern cathedral is the shopping mall and the road to hell is paved with good inventions!

Perhaps the most dangerous invention we have ever come up with is a group of experts who all share the same value system, because it is difficult for anyone in that group to challenge the shared value. Indeed, the danger is in the fact that the shared value is invisible. It is not easy to question the way we see the world: our paradigms. We do not notice the lens we see through until it cracks or clouds a little.

In her book The Global Citizen, Donella Meadows, one of the

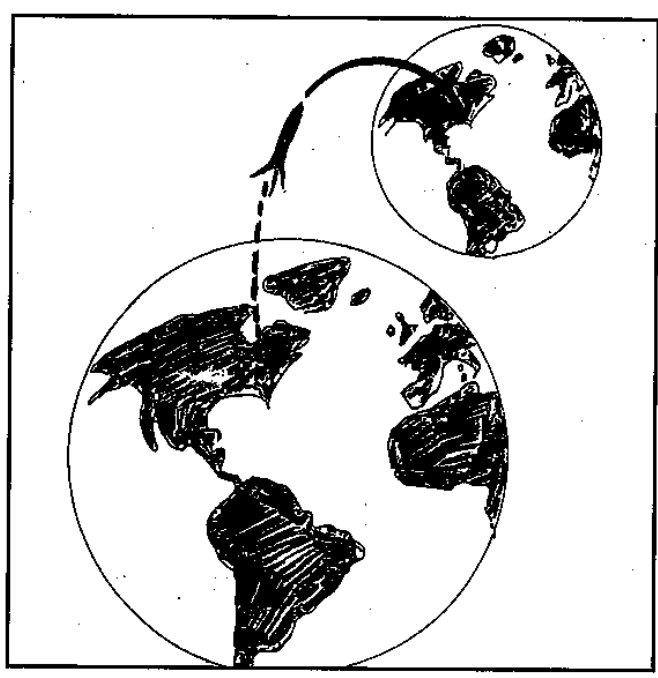

FIGURE 1 . authors of the Limits to Growth, gives a list of seventeen common assumptions, which in her view underpin our present paradigm (1). I would summarize the paradigm this way: "We are living on this planet as if we had another one to go to!"

This paradigm is shared by the most powerful people on our planet, from the presidents of countries to the chief executive officers of multinational corporations. Economic growth is offered as the answer to every social and political problem. We

even have Nobel Prize-winning economists rationalizing living off "capital" (finite resources) rather than "income" (renewable resources) as far as our global budget is concerned. Presidents can talk about "globalization of the economy" as an accepted "good" without having to trouble about the consequences of accelerating the consumption of finite resources, or exasperating global warming.

In my view, the diagram in figure 2, taken from Mary E. Clark's book Ariadne's Thread (2), should be on the wall of every classroom in the world, and while we are at it, in the office of every president and the boardroom of every corporation. It shows the projected consumption of the world's fossil fuel on a 10,000-year time line, with the present set at 


\section{FIGURE 2.}

The World's Consumption of Fossil Fuel as Estimated by Hubbert, and Projected on a 10,000 Year Timescale.

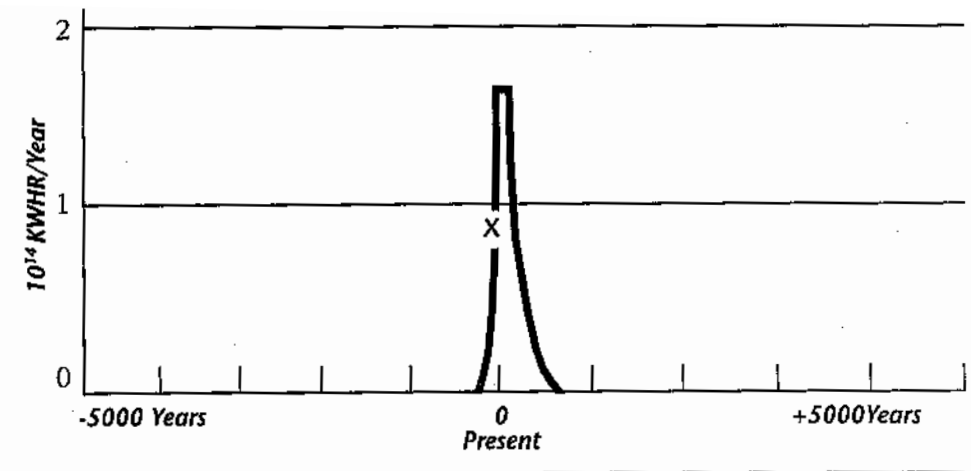

Source: Adapted from A. A. Bartlett, 'Forgotten Fundamentals of the Energy Crisis', American Journal of Physics, 46 (1978) p. 885, and figure $69 \mathrm{in} \mathrm{M}$. King Hubbert, A National Fuels and Energy Policy Study, Serial 93-40 (92-75), Part I (1973) (Washington, DC: US Government Printing Office, 19780

time zero. Seen from point X on the curve nothing looks amiss. Looking backward from X looks like the march of progress. It is looking forward that is so difficult. In our universities we have professors moving their students to tears by plays written over 2,000 years ago, and symphonies composed a few hundred years ago, but hardly a wrinkle furrows their brow over the people who will have to struggle in the future without any of this fossil fuel. It is this seemingly abundant supply of fossil fuel that props up so many wasteful ways of doing things on our planet. In my view, it props up polluting agriculture, inefficient transport systems and obscenely wasteful material use. In short, it props up overconsumption. It also provides the lens through which we see the world.

The municipal waste issue scratched my personal lens. In particular, the way I saw the world changed when it was proposed to build a trash incinerator in our county in northern New York. As I studied the proposal I was shocked. Not only did it reveal the serious threat posed to living things by the introduction of persistent toxins like dioxins into the environment, but it raised fundamental questions about the way we handle resources on a finite planet. Moreover, it raised disturbing questions about the way local, state, and federal governments resolve scientific and social questions like these. Involvement in this issue has 
had a major Impact on my career and life. The dioxin issue has resulted in my coauthoring several papers on dioxin, and my concerns about the waste issue has resulted in my helping communities-largely, grassroots citizens' groups-in over thirty countries. Hopefully, some of the things learned in this process can be of help when we are considering the future of scientific education in general and science education abroad, in particular.

What kind of questions could scientists have asked that would have allowed us to avoid problems like dioxin? What kind of questions could decision makers ask that would allow us to avoid a waste crisis? What kind of questions do we all need to ask in order to move society toward sustainability? How can this kind of questioning be introduced into the science curriculum? How does all this relate to studying science abroad?

\section{Dioxin}

Dioxin is a name used to describe two families of compounds called polychlorinated dibenzo dioxins (PCDDs) and polychlorinated dibenzo furans (PCDFs). These two families contain 210 different substances, 17 of which include the most toxic substances ever made in a laboratory. If they had been commercial products, they would have been banned years ago. Unfortunately, they are unwanted byproducts of very powerful industries, including the paper industry (dioxins are generated whenever paper is bleached with chlorine), the chemical industry (dioxins are produced when many organochlorine compounds are made) and the incineration industry (dioxins are produced whenever organochlorine compounds are burned).

Industrial scientists have argued that dioxin has been with us since the advent of fire (3), and while it is extremely toxic for animals, humans are not very vulnerable. However, these are positions with which the United States Environmental Protection Agency (US EPA) does not agree. In a draft document released in September 1994, after an exhaustive three-year review of the literature on dioxin, by both their own in-house scientists and leading dioxin researchers from around the world, the US EPA concluded that (1) dioxin's toxic effects are worse than we originally thought; (2) the average American has a body burden 
of dioxin that is within a factor of ten of where we would expect to see effects; (3) most of this dioxin is coming to us in our food and it is getting there largely from human activities, particularly incineration $(4,5)$.

US EPA scientists like Dr. Linda Birnbaum (Director of the Health Effects Research Laboratory, Office of Research and Development), give little credence to the notion that humans are capable of handling dioxin differently from animals. What we know about the mechanisms of action of dioxin are common to both humans and other animals (6). Specifically, all living species in evolution above boneless fish contain in their tissues the protein receptor (the Ah receptor) to which dioxin avidly attaches itself when it enters our tissues. The fact that this protein receptor emerged so early in evolution and survived in so many different species points to its playing a very important and fundamental role in biological processes.

While scientists have not yet identified the natural substance that should bind to this receptor, we do know that when dioxin becomes attached to it, it migrates to the nucleus, where it attaches itself to the DNA and causes certain genes to be switched on. This results in the production of different proteins in the cell, which in turn changes the chemistry of the cell. Thus, dioxin functions like a typical fat soluble hormone.

Hormones are chemical messengers that take messages from the glands in which they are made (endocrine glands) to specific tissues, where they regulate chemical reactions. The problem with dioxin is that it delivers the wrong messages (or the right messages at the wrong time), causing "disregulation" of cellular chemistry. Unfortunately, because hormones function at such low concentrations (micromolar to picomolar levels), substances that mimic natural hormones are extremely potent. Very little is needed before the message system is scrambled.

Birnbaum has called dioxin the most potent disregulator we have ever studied. It affects the levels of several hormones, including estrogen, testosterone, insulin, glucocorticoid, and thyroid hormones. Adding still further to our concern is the fact that once dioxin has entered our bodies, our normal detoxifying mechanisms don't get rid of it. It is highly persistent. Its half-life is seven years. Being fat-soluble, it gets deposited in our fatty tissues and bioconcentrates over our lifetime. 
Unlike a man, a woman has a way of getting rid of fat-soluble substances. This occurs when she has a baby. First, the dioxin moves from the mother's fat across the placental membrane to the fetus and then, after the baby is born, more dioxin moves from the mother to the baby via breast milk. Thus the highest doses of these extremely potent disregulators of living chemistry are going to our babies.

In my view, the most important paper yet published on dioxin appeared in the British medical journal The Lancet, on May 23, 1992, in the form of a letter from eight Dutch scientists (7). These scientists examined the thyroid metabolism of babies born to thirty-eight women in Holland. They divided the babies into two groups, those whose mothers had high background levels of dioxin in their breast milk, and those who had low background levels. The average levels of the two groups differed by about a 2:1 ratio (37.5 versus 18.6 parts per trillion in the milk fat). The researchers showed that the babies had a significant difference in their thyroid metabolism. This is the first paper that has shown that background levels of dioxin are capable of causing changes in human chemistry. Subsequent studies have shown that significant differences in neurological development in newborn babies are relatable to the levels of dioxins (and poly chlorinated biphenyls) to which they are exposed before and after birth (8). The good news is that where aggressive steps have been taken in Germany and Holland to address the source of dioxins going into the environment, the levels of dioxins in both cows' milk and mothers' milk have fallen. We can only hope that these decreases continue.

Meanwhile, there are indications that dioxins, furans, and (the closely related) PCBs are only the tip of a much larger iceberg of synthetic chemicals that are capable of interfering with hormonal signals at the early stage of human life. A recent book by Theo Colborn and others, Our Stolen Future (9), lists over fifty chemicals, present in pesticides, plastics, detergents, and other commercial products, which mimic or interfere with hormones. They hypothesize that in addition to causing impacts on the sexual development and reproductive ability of many wildlife species, these chemicals are contributing to some serious human health problems. Specifically, they ask whether the dramatic increases in breast, prostate and testicular cancer, as well as the fall in sperm counts, which have occurred in many industrial countries since 
1940, may be partially explained by the interference of these synthetic hormones with human sexual development, especially at the fetal stage.

So what kind of questions, if asked at the right time, might have averted these dangers? With hindsight we can suggest the following: (1) As nature does not make persistent substances (her strategy, both inside the body and within ecosystems, is one of constantly building up and breaking down her constituent molecules), should we not be careful about introducing persistent substances into the environment, especially fat-soluble ones which can bioaccumulate in the food chains? (2) More specifically, as nature did not introduce the carbon-chlorine bond into the mainstream of biochemistry (it appears in seaweeds, fungi, and some plants but it does not appear in any terrestrial mammal), should we not be careful about our industrial uses of chlorine? Currently, the world manufactures 40 million tons of chlorine annually and most of that goes into the production of such products as solvents, pesticides, and the plastic poly vinyl chloride (PVC). Most of these organochlorines are fat-soluble and highly persistent in the environment. Over half the endocrine disrupters identified by Colborn and others are oganochlorines.

What kind of scientific training would prepare a scientist to ask these kinds of questions, before the calamity rather than after it? Can we teach science students to be wise as well as clever? Is one of the differences between being clever and wise, the difference in the time scale we use to judge the success of an outcome? Is it possible that indigenous science (wisdom) has some help to give Western science on such questions? Would someone concerned about impacts on the "seventh generation" have been more likely to ask a question about the effects of persistent things?

One would hope that encouraging science students to study abroad would allow an interchange on these kinds of questions.

Moving from past mistakes to a consideration of the future, we might ask, what would a sustainable chemical industry look like? As countries in the South develop their own chemical industries, are they going to copy our dirty and wasteful production processes? Are they going to make the chemicals we are no longer permitted to make? Or are they going to jump into clean production? Unfortunately, based on a recent 
visit I made to a chemical complex in Gujarat, India, early answers to these questions are not encouraging.

\section{Waste Management}

Waste management is another area of society littered with wrong questions. In my view, the fundamental problem of allowing technologists and global economists to define our future on a finite planet, is that they are imposing a linear society on a system that otherwise functions in circles and cycles. Their notion of development is to take raxv materials through production and thence through consumption, a process greatly stimulated and, I would say, overstimulated by advertising and thence to waste. Their definition of progress seems to be how fast they can convert raw materials into waste!

At this point we call in "experts" and ask them an albeit innocent, but massively bad, question. We ask, "Where shall we pur the waste?" This bad question has resulted in bad answers for over one hundred years. Not only has it resulted in a huge waste of time, money, and resources, but it has also resulted in unnecessary abuse of the environment, human health, and human rights.

The question "Where shall we put the waste>" leads either to a hole in the ground or a hole in a machine: either to landfills or to incinerators. Very few people in the world want to live near either a landfill or an incinerator. As communities organize against them, decision makers look farther afield for their location. Eventually this search becomes one in which the powerful dump on the weak and the rich on the poor. It fuels environmental injustice. The exportation of waste becomes the exploitation of people. One example of how ridiculous this can become was offered by an American company that tried to build an incinerator in Khulna, Bangladesh, to receive and burn trash from New York City! Fortunately, local activists organized to defeat this project.

Most citizens are oblivious to the injustices perpetrated in these waste battles. It is usually only the victim communities that see the way that the "regulatory-industrial-complex" maneuvers to force the unwanted "waste solution" on their heads. To do this, an extremely well paid rogues' gallery of consultants, regulators, lawyers, equipment 
manufacturers, and public relations experts has specialized in obscuring the issue with environmental impact statements, health risk assessments, and staged public hearings. However, despite the odds, many communities around the world have been able to fight off these bad solutions. For example, since 1985 in the United States over three hundred trash incinerator proposals have been stopped largely by public opposition (10).

The reason that so many "waste experts" ask the wrong questions is that they think with the wrong end of their bodies. They are what I call back-end thinkers. I have a short story to illustrate the phenomenon of back-end thinking. Imagine a back-end thinker coming home from work. He finds the bathtub overflowing. Alarmed, he quickly grabs a cup to empty the bath. This is not fast enough, so he grabs a bucket. This is still not fast enough, so he goes to a foot pump. But even this is not fast enough, so he goes to an electric pump-and powers it with a nuclear power station-all in an effort to empty the bathtub before the water damages the floor. At this point, his wife comes home and switches off the tap! She is a front-end thinker. Einstein described this situation some time ago when he said, "A clever person solves a problem, a wise person avoids it."

At the back-end of the waste problem we have many clever engineers designing new plastic liners for landfills and complicated air pollution control devices for incinerators.

However, if we apply front-end thinking to the waste crisis, we realize that the question is not "where do we put the waste?" but "how do we unmake the waste?" Our key problem is not waste management but resource management: not managing waste but managing ourselves. Nature makes no waste; waste is a human invention. Waste is a verb, not a noun. Waste is made by mixing all our discarded materials together; it is unmade by keeping them separate. When we keep them separate the solutions are rational. We can reuse whole objects; recycle synthetic materials back to industry and biological materials back to nature (composting). Even more important, we can reduce our need for trivial things. As Mahatma Gandhi said, "The world has enough for everyone's need, but not for everyone's greed."

To summarize, with front-end thinking the waste problem is relatively easy. It involves looking into the trash can and asking rational 
questions about what to do with the different materials we place there. If, on the other hand, we give in to back-end solutions and put all our discarded materials into one plastic bag and pay someone to take it away, the solution from this point on gets more and more irrational and expensive. Moreover, with back-end solutions, more and more of the taxpayers' money we spend on the waste problem is going to go into the coffers of multinational corporations, create very few jobs, and leave the community. We will also have squandered a golden opportunity to take responsibility (the fourth and most important "R") not only for our own waste but also for our connection to the global resource crisis.

Communities move further toward the front-end answers when they have the gumption to say to manufacturers, "If we can't reuse it, recycle it or compost it, you shouldn't have made it." So many of the problematic materials in our waste stream are poorly designed products and packaging. Throwaway packaging is industry's way of externalizing its packaging costs onto the community.

We simply can't run a throwaway society on a finite planet. In this context, landfills simply bury the evidence and incinerators burn it. We have to face the problem and the ultimate problem is the contradiction between overconsumption and sustainability. But challenging overconsumption isn't going to be easy.

\section{Overconsumption}

In industrialized countries we have become addicted to our overconsumptive lifestyles. Alan Durning, in his brilliant book How Much is Enough?, gives a very lucid account of the selling of overconsumption to the American people.

For example, he tells us how in 1958, Victor Lebow, a retail analyst, declared that "Our enormously productive economy demands that we make consumption our way of life, that we convert the buying and use of goods into rituals, that we seek our spiritual satisfaction, our ego satisfaction, in consumption ... We need things consumed, burned up, worn out, replaced and discarded at an ever increasing rate" (11). 
As crass as this statement appears, in my view it accurately describes the attitude that, particularly in the hands of multinational corporations, is driving human civilization to the brink.

It was the poet T. S. Eliot who spotted that it might not be the cataclysmic that brings us to our knees but rather the trivial, when he declared in his poem The Hollow Men,

This is the way the world ends, not with a bang but a whimper (12).

Blumberg and Gottlieb in their book War On Waste give an example of such a "whimper" when they inform us that U.S. plastic manufacturers anticipated that the production of the squeezable ketchup bottle (and it is hard to believe in a happy life without a squeezable ketchup bottle!) would increase from 300 million units in 1985 to 29 billion units in 1995(13). A simple calculation would indicate that with a world population approaching 6 billion, and assuming equity (which, of course, we can't!), each year, every person on our planet, could be the proud possessor of FIVE squeezable ketchup bottles. We can only assume that in the minds of those who run the multinational petrochemical industry this potential for enormous human satisfaction justifies chopping down rain forests, polluting the oceans, and putting endocrine disrupting chemicals into our children's bodies.

If one asked representatives of the plastics industry the reason for developing the squeezable ketchup bottle rather than simply making a glass ketchup bottle with a wider mouth, they would probably answer, "Consumer demand." However, I think we all know how it really happens: the use of modern advertising techniques, especially on television. In industrialized societies, watching television has become the number-one human activity, second to work and sleep. The reason that television is so popular is that it requires practically no expenditure of human effort whatsoever. All one needs to "consume" it is to hold one eyelid open about one eighth of an inch. If we fall asleep it doesn't matter because that's what we are going to do next anyway. One of the prices that we pay, as we live (or rather die) on the couch watching thirsty, sick, too fat, sexually frustrated, and we need a new car! 
FIGURE 3.

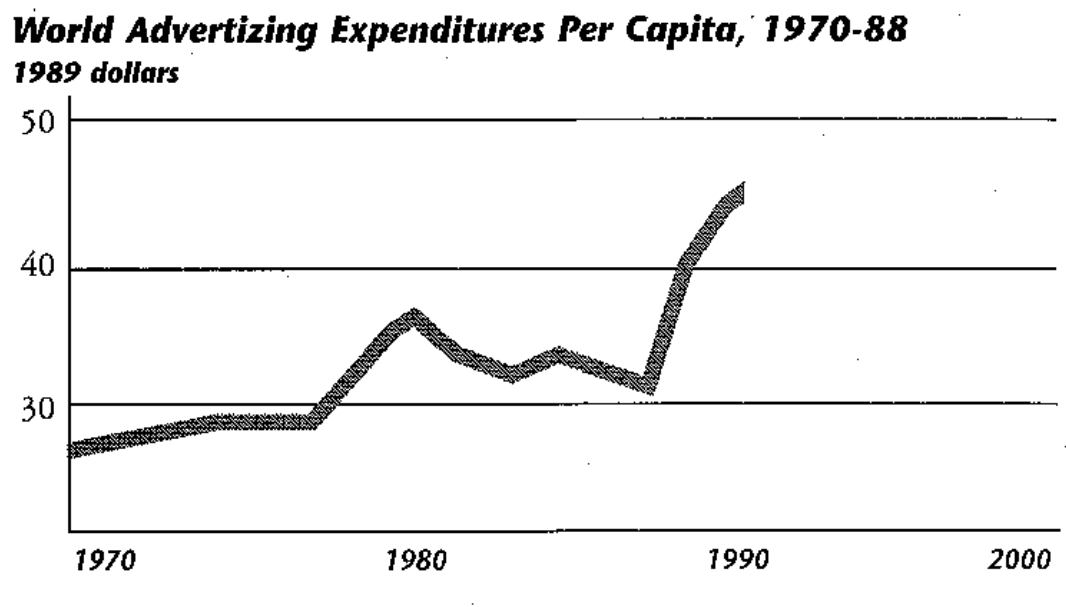

According to Paul Hawken, in the Ecology of Commerce, by the time an American teenager has left high school, he or she will have watched over 350,000 TV commercials (14). He or she is programmed for life-an overconsuming life. This is not just an American problem. According to Alan Durning, world advertising sales are increasing exponentially (15) (see figure 3).

Another indication of where our planet is heading is to note that the most popular program worldwide is Baywatch. This is "consumed" by over 1 billion people each week.

Unfortunately, what we are exporting to the world, is the great twentieth-century illusion: the more we consume, the happier we will become. That this is an illusion can be confirmed by a study of America's drug, crime, mental health, and poverty problems. According to Durning, we are four-and-a-half times richer today than our greatgrandparents were at the turn of the century (17), but we are certainly not four-and-a-half times happier, whatever the impression gained by viewers of Baywatch.

Thus, we are bought back to what I believe to be the most important questions of our time: (1) How much is enough? (2) What do we really need to be happy? (3) How can we be happy and live a sustainable lifestyle? (4) How can we be happy and not deprive others (others in 


\section{FIGURE 4.}

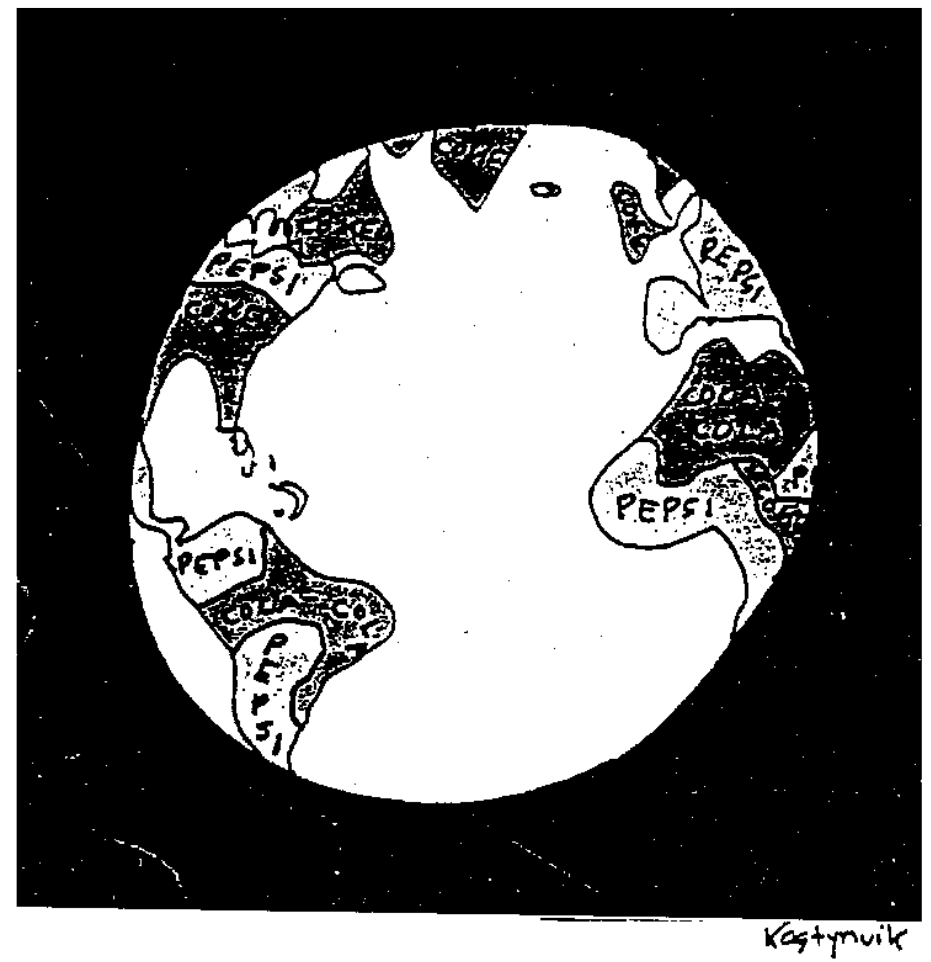

faraway places and faraway futures) of their rightful share of happiness? In short, how can we overthrow overconsumption before it overthrows us?

These are far simpler questions to ask than to answer. The trouble today is that our technological answers are drowning out our social ones.

Science, Arrogance, and Sustainability

So how can a change in the scientific curriculum relate to these questions? The key necessary change in my view is the need to inculcate a sense of humility. We are suffering from scientific and technological arrogance. I define arrogance as ignorance backed up with overconfidence. We don't know all the answers but we behave as if we do. We didn't know all the answers to nuclear power but we pursued it 
anyway. We didn't know all the answers to the long-term effects of putting persistent chemicals into the environment, but we did it anyway. We didn't know all the answers about putting fluoride into our drinking water, but we did it anyway. We didn't know all the answers to the pollution produced from burning trash, but we did it anyway. We don't know all the answers to putting genes from one species into another, but we are doing it anyway. We don't learn from our mistakes. The arrogance continues. As Mark Twain said, "History may not repeat itself, but it sure does rhyme!"

At the root of our arrogance is the notion that we are somehow smarter than nature, bigger than nature, outside nature, in control of nature. I am reminded of E. F. Schumacher's incisive comment about man's battle against nature: "If he won the battle, he would find himself on the losing side" (18).

Hand in hand with our lack of humility with respect to natures processes and limitations is our lack of humility with respect to the wisdom of indigenous peoples. Yet their wisdom, their science, their agriculture, and their medicine were set within nature's limits. Their lifestyles were sustainable. Ours are not.

I am not saying we should return to the Stone Age. I am not saying we should reject all science and technology. But I am saying it's time to start rejecting the trivial. Let us begin to sort out the sensible from the stupid, the sustainable from the nonsustainable. As far as overconsumption is concerned, we in the northern industrial countries have to set a far better example before our wasteful ways are copied wholesale by all of Asia, Africa, Latin America, and Eastern Europe.

Some would argue that sustainability is an intellectual luxury in which only the affluent can engage. They would argue that only a massive globalization of the economy will begin to deal with the issue of poverty in southern countries. However, there are a number of economists and writers who have argued convincingly that globalization will have the opposite effect, namely that it will widen the gap between the rich and poor. In a recent book, Divided Planet: The Ecology of Rich and Poor, author Tom Athanasiou quotes Jacques Attali, the founding president of the European Bank for Reconstruction and Development, as saying, "In the coming world order, there will be winners and there 
will be losers. The losers will outnumber the winners by an unimaginable number"(19).

Books such as Small is Beautiful, by E. F. Schumacher (1973) (20), For the Common Good, by Herman Daly and John Cobb (1989) (21), The Growth Illusion, by Richard Douthwaite (1992) (22), The Ecology of Commerce, by Paul Hawken (1993) (23), When Corporations Rule the World, by David Korten (1995) (24), and Get a Life! by Wayne Roberts and Susan Brandum (1995) (25), all stress the need for small-scale development and the localization of the economy as the best ways of both tackling poverty and protecting the environment.

The key word, for any scientist wishing to make a mark on the future, is elegance. We need elegant solutions. We need power plants that look more like a leaf than a nuclear reactor. We need to live off income (renewable resources), not capital (finite resources). We need to grow food in ways that harmonize with ecosystems, not ways that obliterate them. We need to eat lower on the food chain, so that more people can eat.

We will need some machines, but even more important, we will need to know when to turn them off. We need to recognize that in the next century the focus is going to shift from technological progress to social progress. We need to switch off the television, at least one night a week. We need to make our own entertainment where we live, not simply receive electronic signals from somewhere else. We need to build our lives around relationships with other people, not around the collecting of things. We need genuine community development. We need to reconnect: reconnect with the soil that nourishes us and reconnect with the people around us. Without these connections, what does life mean? Attention needs to shift from the city to the village. From the whiz kids to our elders. From bureaucracy to democracy. From the expert to the citizen. From the scientist to the poet.

Conclusion

For the scientist it is not enough to be able to manipulate matter; he or she must think about the consequences of that manipulation. Before every technological change we wish to make, we must ask whether it is 
sustainable. For example, before tackling the question "How can we make the most fuel-efficient car that has ever been made?" it may be more appropriate to ask, "How can we design a community that does not need to use cars?" More than anything else, we need to slow down. The planet cannot long withstand our enormous appetites. In my view, the opposite to overconsumption is community development. We need to reconnect. We need to learn to belong to a place of our own. Sometimes it is easier to appreciate such a place from a distance. Perhaps, for every experiment our students conduct, they should read at least one poem.

Mary E. Clark quotes N. Scott Momaday, a Kiowa Indian, in an informal poem that contains the kind of ideas our students should be confronting: "You say that I use the land and I reply, yes, it is true; but it is not the first truth. The first truth is that I love the land: I see it is beautiful: I delight in it; I am alive in it" (26).

At the Pew Foundation Symposium on International Science and Engineering Education (Cornell University, June 9-12, 1996), Ochong Okelo informed us that in Kenya they have a saying, "I am, because sve are." In the television series, The Africans, host Ali Mazrui concluded by saying: "The world has learned to dance to the tune of the United States. But the United States has yet to listen to the concert of the world" (27). Let us hope, when science students study abroad they will be able to participate in this concert and delight in it. Such shared exchanges represent the best form of consumption and our best hope for the kind of attitudinal changes that can prepare the way for a sustainable future.

\section{References}

1. Meadows, D.H. (1991) The Global Citizen. Washington, DC: Island Press.

2. Clark, M.E. (1989) Ariadne's Thread. New York: St. Martin's Press.

3. Bumb, R.R., W.B. Crummett, S.S. Cutie, J.R. Gledhill, R.H. Hummel, R.O. Kagel, L.L. Lamparski, E.V. Luoma, D.L. Miller, T.J. Nestick, L.A. Shadoff, R.H. Stehl, and J.S. Woods (1980) Trace Chemistries of Fire: A Source of Chlorinated Dioxins. Science 210: 385-390. 
4. USEPA (1994) Health Assessment Document for 2,3,7,8Tetrachloro-dibenzo-p-Dioxin (TCDD) and Related Compounds. Volumes I, II, and III. Review Draft. EPA/60o/BP-92/oo1a,b,c.

5. USEPA (1994) Estimating Exposure to Dioxin-Link Compounds., Volumes I, II, and III. Review Draft. EPA/60o/6-88/oo5a,b,c.

6. DeVito, M.J., L.S. Birnbaum, W.H. Farland, and T.A. Gasiewicz (1995). Comparisons of Estimated Human Body Burdens of Dioxinlike Chemicals and TCDD Body Burdens in Experimentally Exposed Animals. Environmental Health Perspectives 103: 820831.

7. Pluim, H.J., J.G. Koppe, K. Olie, J.W. v.d. Slikke, J.H. Kok, T. Vulsma, D. van Tijn, and I.J.M. de Vijlder (1992). Effects of Dioxins and Thyroid Function in Newborn Babies. The Lancet. 339:1303.

8. Huisman, M., C. Koopman-Esseboom, V. Fidler, M. Hadders-Algra, C.G. van der Paauw, L.G.M. Th. Tuinstra, N. Weisglas-Kuperus, P.J.J. Sauer, B.C.L. Touwen, and E.R. Boersma (1995). Perinatal Exposure to Polychlorinated Biphenyls and Dioxins and Its Effect on Neonatal Neurological Development. Early Hum Dev. 41:111127.

9. Colborn, T., D. Dumanoski, and J.P. Myers (1996). Our Stolen Future. Boston: Little, Brown and Co.

10. Connett, E. and P. (1994) Since the 1980's a Minimum of 280 Proposals to Build Municipal Waste Incinerators in the U.S. Have Been Defeated or Abandoned. Waste Not. \#283-294. Canton, NY.

11. Durning, A. (1992). How Much Is Enough? New York: W.W. Norton and Co., p. 21.

12. Eliot, T.S. (1961). Selected Poems. London: Faber and Faber.

13. Blumberg, L., and R. Gottlieb (1989). War on Waste. Washington, DC: Island Press, p. 267.

14. Hawken, P. (1993). The Ecology of Commerce. New York:

Harperbusiness, p. 131.

15. Durning, A., op. cit., p. 23.

16. Kostyniuk, B. (1991). Cartoon. Adbusters Quarterly. 1.4 rear cover.

17. Durning, A., op. cit., p. 23. 
18. Schumacher, E.F. (1989). Small is Beautiful. New York: Harper and Row (1989 edition), p. 14.

19. Athanasiou, T. (1996). Divided Planet. Boston: Little, Brown and Co., frontispiece.

20.Schumacher, E.F., op. cit.

21. Daly, H.E., and J.B. Cobb, Jr. (1989) For the Common Good. Boston: Beacon Press.

22. Douthwaite, R. (1992). The Growth Illusion. Tulsa: Council Oak Books.

23. Hawken, P., op. cit.

24. Korten, D.C. (1995). When Corporations Rule the World. West Hartford, CT.: Kumarian Press.

25. Roberts, W., and S. Brandum (1995). Get a Life! Toronto: Get a Life Publishing House.

26. Clark, M. E., op. cit., p. 474.

27. Mazrui, A. (1986). The Africas: The Nature of a Continent. (TV series). Washington, DC: WETA and BBC.

Figure Captions

FIGURE 1. Our current paradigm: we are living on this planet as if we had another one to go!

FIGURE 2. The world's consumption of fossil fuel as estimated by Hubert and project on a 10,000 year timescale. It will take a brief five centuries to consume it all (Figure 2-7 from reference 2).

FIGURE 3. World advertising expenditures per capita, 1970-88 (Figure 9-1 from reference 10).

FIGURE 4. What the world might look like if the globalization of advertising continues unchecked (cartoon from Adbusters Quarterly, (1991) Volume 1 number 4, rear cover). 